\title{
A legelés léptékfüggő hatásai szikes- és homoki gyepek fajgazdagságára
}

\author{
Godó Laura \\ Debreceni Egyetem Ökológia Tanszék \\ 4032 Debrecen, Egyetem tér 1 \\ e-mail: godolaura0306@gmail.com
}

\begin{abstract}
Összefoglaló: Az extenzíven kezelt legelőknek jelentős szerepe van a gyepi biodiverzitás fenntartásában. Vizsgálatunkban a legelés léptékfüggő hatásait vizsgáltuk két szikes és egy homoki gyepi közösség fajgazdagságára és fajösszetételére. Gyeptípusonként öt extenzíven legelt és öt kezeletlen mintavételi helyen, egymásba ágyazott kvadrátok sorozatával mértük fel a növényzetet. Kimutattuk, hogy a legelés hatása eltérö a homoki és a szikes gyeptípusokban, és kis léptékben is jelentösen befolyásolja a fajgazdagságot. A szikes gyepekben a fajgazdagság kezeléstől függetlenül nőtt a kvadrátméretek növekedésével, illetve magasabb volt a legeltetett területeken. A specialista fajok száma is a legeltetett területeken volt magasabb. A homoki gyepekben a specialisták fajgazdagsága jelentősen lecsökkent, a gyomoké megnőtt a legelés hatására. Eredményeinkre alapozva, a közepes intenzitású, tradicionális legeltetés alkalmas lehet a szikes gyepek fajgazdagságának megőrzésére, míg a homoki gyepekben a kevésbé intenzív vagy rövidebb időtartamú legeltetést javasoljuk.
\end{abstract}

Kulcsszavak: gyepkezelés, gyepi specialista fajok, gyomok, legelő, kvadrátméret, térbeli heterogenitás

\section{Bevezetés}

Európa szárazgyepei számos ritka és veszélyeztetett fajnak nyújtanak otthont, számos specialista növény- és állatfaj kötődik ezekhez az élőhelyekhez (Deák et al. 2016a, Valkó et al. 2016a). A szárazgyepek kiterjedése jelentősen lecsökkent az elmúlt évszázadok során, föként a városiasodás és a szántóföldi múvelésbe vonás miatt (Deák et al. 2016b, c, Lindborg et al. 2014,). Az élőhelyvesztés mellett a tájhasználatban bekövetkezett változások, elsősorban a gyepek felhagyása, is jelentősen veszélyeztetik a fennmaradt gyepek fajgazdagságát (Poschlod \& Wallis De Vries 2002, Valkó et al. 2012). Ahhoz, hogy a fennmaradt szárazgyepek fajkészletét megőrizzük, nélkülözhetetlen, hogy újra bevezessük a hagyományos gazdálkodási formákat (Tälle et al. 2016, Török et al. 2014, Valkó et al. 2016b). 
A vadonélő legelő állatok jelentős szerepet játszottak a gyepek kialakulásában és fenntartásában a szelektív biomassza eltávolítás és taposás révén (Poschlod \& Wallis De Vries 2002). Az extenzíven kezelt legelőknek döntő szerepe van a biodiverzitás fenntartásában mind lokális, mind táji léptékben (Tölgyesi et al. 2015). Számos tanulmány kimutatta, hogy a közepes intenzitású legeltetés növeli a gyepi növényközösségek diverzitását, mivel visszaszorítja az erős kompetíciós képességü domináns fajokat, így lehetővé teszi a kevésbé kompetitív fajok széles skálájának együttélését (de Bello et al. 2007, Metera et al. 2010, Deák et al. 2018). A gyepek fajgazdagságának fenntartása érdekében a természetvédelemben szükség van olyan költséghatékony kezelési módszerekre, amelyek mind a gazdasági fenntarthatóság, mind a biodiverzitás megőrzésének szempontjából megfelelőek (Tóth et al. 2016, Török et al. 2014). Az extenzíven tartott, hagyományos szarvasmarhafajták alkalmasak lehetnek a természetmegőrzési célok megvalósításához Európa számos élőhelyén (Mann \& Tischew 2010, Kovácsné Koncz et al. 2015). Kutatásunk célja a legeltetés léptékfüggő hatásának vizsgálata volt három szárazgyepi közösségben: Achilleo setaceae-Festucetum pseudovinae, valamint Artemisio santonici-Festucetum pseudovinae szikes gyepekben és Potentillo arenariae-Festucetum pseudovinae homoki gyepekben (a továbbiakban füves szikes puszta, ürmös szikes puszta és homoki legelö).

Kutatási kérdéseink a következők voltak: (1) Léptékfüggö-e az extenzív legeltetés hatása a növények fajgazdagságára a szikes és homoki gyepekben? (2) Hogyan befolyásolja az extenzív legeltetés a specialista, generalista és gyomfajok arányát ezekben a gyeptípusokban?

\section{Módszerek}

Mintavételi területeink az Alföldön találhatóak (Hortobágy: N 47³4', E 21ㅇ 9' és Nyírség: N $47^{\circ} 55^{\prime}$, E $\left.21^{\circ} 41^{\prime}\right)$. A Hortobágyot a nagy kiterjedésủ féltermészetes élőhelyek, mint a szikes és löszgyepek, vizes élőhelyek, sós mocsarak és kis kiterjedésủ mezőgazdasági parcellák mozaikja jellemzi (Burai et al. 2015; Deák et al. 2014a, b, 2015a). Ezzel ellentétben a Nyírség egy erősen átalakított táj, melyben kis kiterjedésü savanyú homoktalajon kialakult homoki gyepek, nedves rétek és homoki tölgyesek fordulnak elő szántóföldekkel, városi területekkel és faültetvényekkel körülvéve (Albert et al. 2014). A Hortobágy tengerszint feletti magassága 88-102 méter között van, az átlagos éves csapadékmennyiség $550 \mathrm{~mm}$ és az átlagos éves középhőmérséklet $9,5^{\circ} \mathrm{C}$ (Deák et al. 2015b). A Nyírség tengerszint feletti magassága 115-150 méter közötti, az átlagos éves csapadékmenynyiség $600 \mathrm{~mm}$ és az átlagos éves középhőmérséklet $10{ }^{\circ} \mathrm{C}$ (Novák et al. 2014). 
A vizsgálat során a három gyeptípusból (füves szikes puszta, ürmös szikes puszta és homoki legelö) legelt és nem legelt területek vegetációját mértük fel. A legeltetett területeket nagytestü szarvasmarha fajtákkal, közepes legelési intenzitással (0,5 állategység/hektár) legeltették április közepétől szeptember végéig. A felmérést megelőzően a legeltetés legalább öt éve folyt. A nem legeltetett területek a legeltetettek közvetlen közelében helyezkedtek el (kevesebb, mint 500 méterre) és legalább öt éve nem legeltettek rajtuk a felmérést megelőzően. Egyéb kezelés nem történt a mintavételi területeken. Gyeptípusonként öt legelt és öt nem legelt területet jelöltünk ki. A felmérésre 2008 júniusában került sor. Annak érdekében, hogy vizsgálhassuk a legelés léptékfüggő hatását, a mintavételi helyek növényzetét egymásba ágyazott kvadrátokkal mértük fel. A kvadrátok méretei: $16 \mathrm{~m}^{2}, 8 \mathrm{~m}^{2}$, $4 \mathrm{~m}^{2}, 2 \mathrm{~m}^{2}, 1 \mathrm{~m}^{2}, 0,5 \mathrm{~m}^{2}, 0,25 \mathrm{~m}^{2}, 0,125 \mathrm{~m}^{2}, 0,0625 \mathrm{~m}^{2}$ és $0,01 \mathrm{~m}^{2}$ (1. függelék az Online Függelékekben). A kvadrátokban feljegyeztük az összes jelenlévő edényes növényfajt.

A Festuco-Brometea, Koelerio-Corynephoretea és Puccinellio-Salicornietea társulástani osztályok fajait specialistáknak tekintettük (Horváth et al. 1995). A fajokat két további csoportba (gyomfajok és generalisták) soroltuk a Borhidiféle szociális magatartástípus besorolás alapján (Borhidi 1995). A ruderális kompetítorokat és gyomokat gyomként kezeltük, míg a generalisták önmagukban képeztek kategóriát. A kezelés, a kvadrátméret, illetve e két faktor interakciójának a teljes fajgazdagságra, valamint a specialisták, generalisták és gyomok fajgazdagságára kifejtett hatását kvadratikus regressziós modellek segítségével vizsgáltuk (R Core Team 2016). Az azonos gyeptípuson belüli, azonos méretü, de különböző módon kezelt kvadrátok teljes fajgazdagságában, továbbá a specialisták, generalisták és gyomok fajgazdagságában tapasztalható különbségek kimutatására Wilcoxon-tesztet használtunk (SPSS 20; Zar 1999).

\section{Eredmények}

Összesen 41 fajt találtunk a füves szikes pusztákon, 24 fajt az ürmös szikes pusztákon és 60 fajt a homoki legelőkön. A legelt és nem legelt füves szikes puszták vegetációja fajkészlet alapján kevéssé különült el, mint a másik két gyeptípus esetében; a közös fajok aránya 43,5\% volt, míg az ürmös szikes pusztánál 29,2\% és a homoki legelőnél 31,6\%. (2. függelék az Online Függelékekben).

A füves szikes pusztákon a legeléstől és a növekvő kvadrátmérettel nőtt a teljes fajgazdagság illetve a specialista, generalista és gyomfajok fajgazdagsága is (1. ábra). Az ürmös szikes pusztákon a legelés és a növekvő kvadrátméret egyaránt növelte a teljes fajgazdagságot és a specialisták és gyomok fajgazdagsá- 

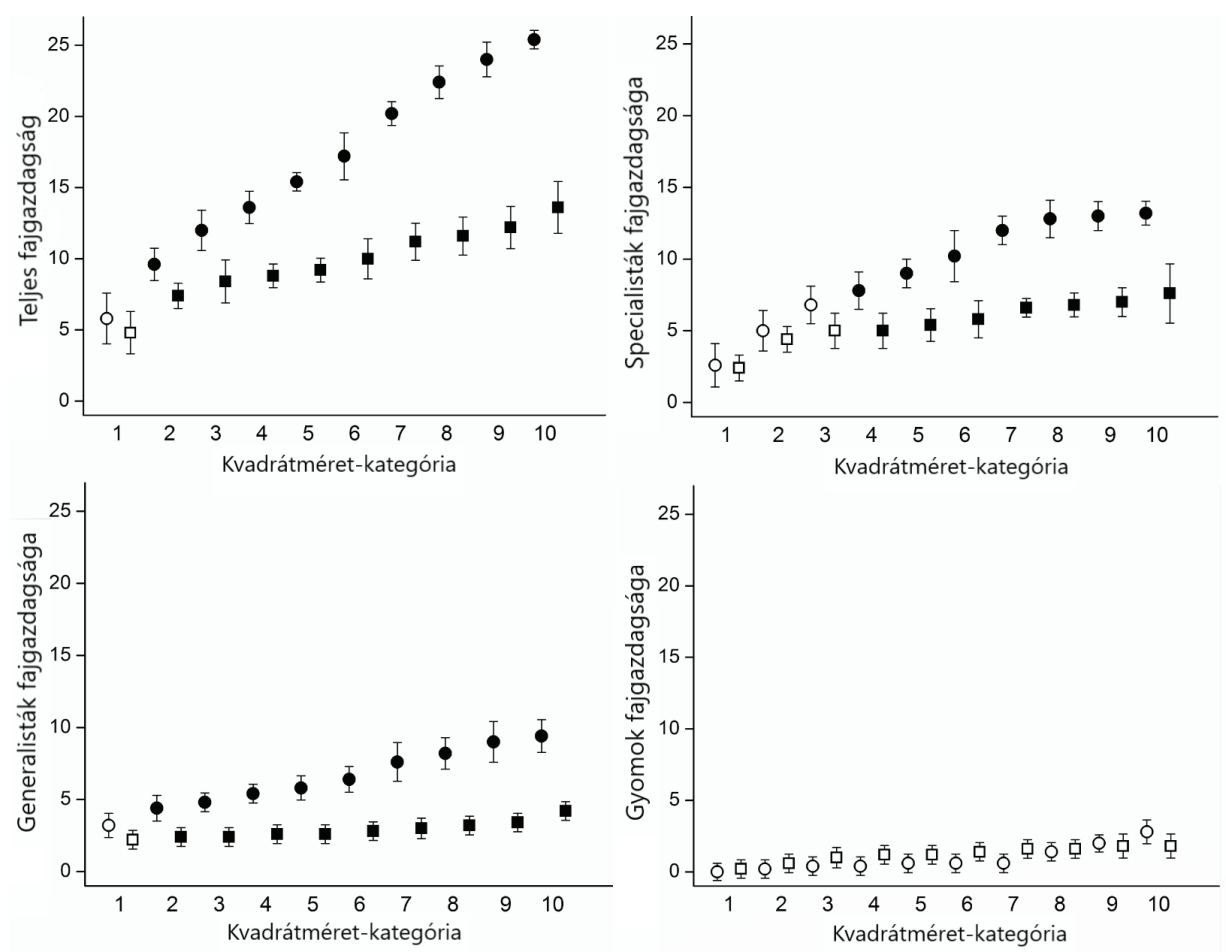

1. ábra: A legelés és a kvadrátméret hatása a teljes fajgazdagságra és a specialisták, generalisták és gyomok fajgazdagságára a füves szikes puszta gyeptípusban. Jelölések: kör - legelt, négyszög - nem legelt. Az azonos méretü, legelt és nem-legelt kvadrátok közötti szignifikáns különbséget a teli szimbólumokkal jelöltük. Az x tengely számozása az egyes kvadrátokat jelöli, növekvő sorrendben. (Wilcoxon signed-rank teszt; $\mathrm{p}<0,05$ ). A hibasávok a standard hibát jelölik.

gát. A generalisták fajgazdasága hasonló volt a legelt és nem legelt kvadrátokban, függetlenül azok méretétől (2. ábra). A homoki legelőkön a legeléstől nőtt a generalisták és a gyomok fajgazdagsága, csökkent a specialistáké, de a teljes fajgazdagságot nem befolyásolta. Minden csoport fajgazdagsága nőtt a növekvő kvadrátmérettel. Szignifikáns interakciót találtunk a legelés és a kvadrátméret között a gyomok fajgazdagságát illetően minden élőhelytípusban (3. ábra).

\section{Értékelés}

Eredményeink azt mutatják, hogy mind a legelés, mind a vizsgált térbeli lépték jelentős hatással volt a szikes és homoki gyepek fajgazdagságára. A legelés ugyanúgy hatott a két szikes közösségben (füves szikes puszta és ürmös szikes puszta), míg a homoki legelőkön eltérö mintázatokat tapasztaltunk. Ez leginkább a külön- 

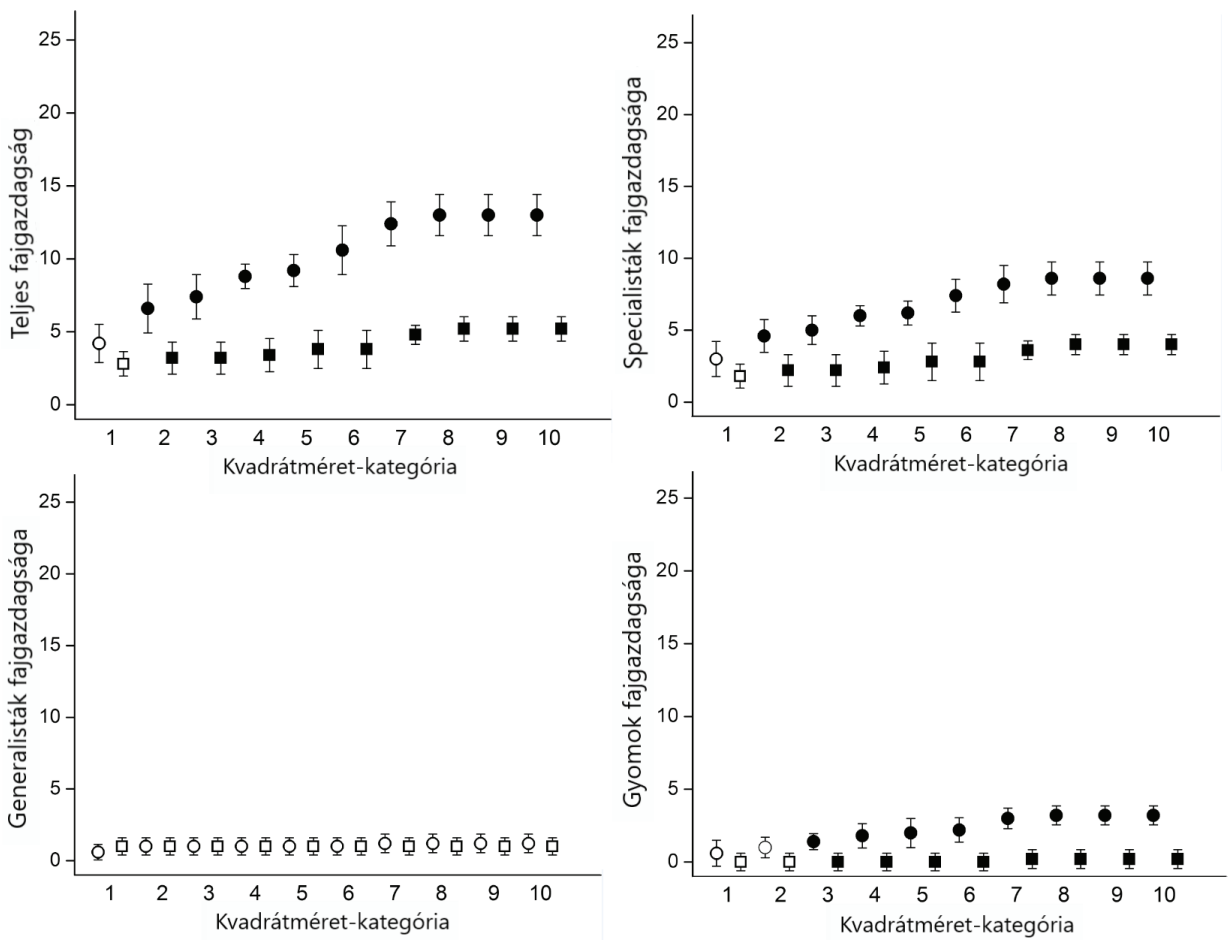

2. ábra: A legelés és a kvadrátméret hatása a teljes fajgazdagságra és a specialisták, generalisták és gyomok fajgazdagságára az ürmös szikes puszta gyeptípusban. Jelölések: kör - legelt, négyszög - nem legelt. Az azonos méretü, legelt és nem-legelt kvadrátok közötti szignifikáns különbséget a teli szimbólumokkal jelöltük. Az x tengely számozása az egyes kvadrátokat jelöli, növekvő sorrendben. (Wilcoxon signed-rank teszt; $\mathrm{p}<0,05$ ). A hibasávok a standard hibát jelölik.

böző élőhelyi sajátosságokkal (pl. talaj sótartalma, nedvessége) és az eltérö táji környezettel magyarázható (Deák et al. 2014a).

Olff \& Ritchie (1998) hipotézise szerint kis térbeli léptékben a fajgazdagság nagyobb a kezelt élőhelyeken, mint a nem legeltekben. Vizsgálatukban kimutatták azonban, hogy ez a mintázat az erősen stresszelt élőhelyeken (például sós talajokon) eltérő lehet, mivel az erős stressz elfedheti a legelés hatását. Az erősen stresszelt közösségekben a legelés gyakran nem befolyásolja a fajgazdagságot, vagy éppen csökkenti azt. Eredményeink nem támasztják alá ez utóbbi elméletet, mivel jelentős növekedést tapasztaltunk mindkét legelt szikes gyeptípus teljes fajgazdagságában a $0,0625 \mathrm{~m}^{2}$-es kvadrátméret felett. A legelés, taposás és ürülék egyenlőtlen eloszlása révén a legelt helyeken kis léptékben tapasztalt heterogenitás a mikro-élőhelyek jobb elérhetőségén keresztül lehetővé tette több faj együttes megjelenését már kis léptékben is (lásd Metera et al. 2010). A fokozott zoochor magterjesztés szintén hozzájárulhatott a magasabb fajgazdagsághoz a le- 

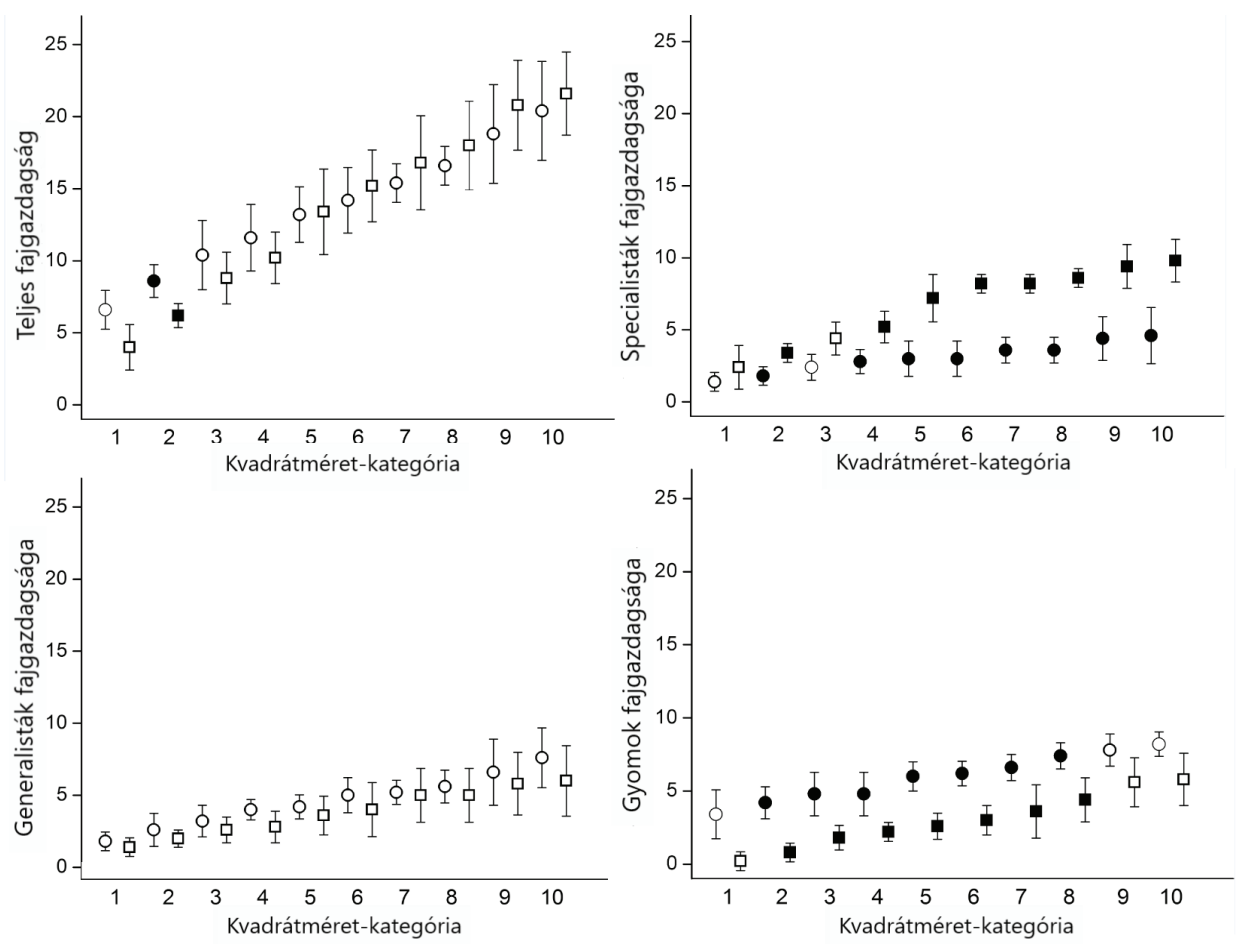

3. ábra: A legelés és a kvadrátméret hatása a teljes fajgazdagságra és a specialisták, generalisták és gyomok fajgazdagságára a homoki legelő gyeptípusban. Jelölések: kör - legelt, négyszög - nem legelt. Az azonos méretü, legelt és nem-legelt kvadrátok közötti szignifikáns különbséget a teli szimbólumokkal jelöltük. Az x tengely számozása az egyes kvadrátokat jelöli, növekvő sorrendben. (Wilcoxon signed-rank teszt; $\mathrm{p}<0,05$ ). A hibasávok a standard hibát jelölik.

gelt területeken, mivel az állatok képesek átvinni egyes fajok magjait a környező területekre a szörzetükön, patájukon és az ürülékükkel (Poschlod \& Wallis De Wries 2002). A specialista fajok összetételében tapasztalt különbségek a talajok adottságaira vezethetők vissza, mivel az ürmös szikes pusztákon számos jó sótürő képességü faj volt jelen, míg a füves szikes pusztákon a szikes és löszgyepi fajokat is megtalálhatjuk (Deák et al. 2014a, b).

A taposás által létrejött nyílt foltokban számos, a szikes gyepekre jellemző, kistermetü gyepi specialista faj tudott megtelepedni, mint a Plantago tenuiflora és Puccinellia limosa. Míg a nyílt foltok alkalmasak voltak a specialistáknak, a sóstressz miatt a gyomok nem tudnak megtelepedni (Valkó et al. 2016b, c). Azt találtuk, hogy a generalisták és gyomok fajgazdagsága az ürmös szikes pusztákon és füves szikes pusztákon alacsonyabb volt, mint a homoki legelőkön. Ez magyarázható a felmért gyepek természetes táji környezetével és a szikes talajadottságokkal (Deák et al. 2014a). A humuszban gazdag felső talajréteg és a mérsékelt 
sófelhalmozódás az alsóbb talajrétegekben a füves szikes puszta gyepekben lehetővé tette a generalisták nagy fajgazdagságát. A generalisták fajgazdagsága növekedett a legelt területeken, még kis léptékben is. A gyomok a legelt területeken kis számban voltak jelen.

A szikes gyepekkel ellentétben a homoki gyepekben a legelés nem volt hatással a teljes fajgazdagságra. Ez annak köszönhető, hogy míg a specialisták fajgazdagsága szignifikánsan csökkent a legelt területeken, a generalisták és gyomfajok aránya jelentősen nőtt. A szikes gyepekkel ellentétben a homoki gyepek specialista fajai kevéssé tolerálták a legelés hatásait. A szikes illetve homoki gyepben tapasztalható eltérő gyomosodási mintázatok több okkal is magyarázhatók. Az egyik ok az élőhely talajtani adottságaiból adódik. Míg a szikes területek kompaktabb, szilárdabb talaja kevésbé van kitéve a legelés általi erózióknak, a homok talaj lazább szerkezete miatt igen sérülékeny (Morgan 2009). Ez a legelt állományokban zavart talajfelszínek kialakulásához vezet, amely alkalmas a gyomfajok megtelepedésére (Tilman 1993). Továbbá a szikes gyepek specialista fajai túlnyomórészt sekély, földfelszín alatt szétterülő gyökerekkel rendelkeznek, így a felszín alatti erős gyökérkompetíció csökkenti a gyomok csíranövényeinek megtelepedési sikerét. Ezzel ellentétben a többnyire mélyen gyökerező homoki specialista fajok kisebb mértékben gátolják a gyomok megtelepedését, mivel esetükben a gyökérkompetíció mértéke kisebb (Jentsch \& Beyschlag 2003, Schenk 2006). A gyomok esetén a legelésnek léptékfüggő hatása volt, amelyet a kvadrátméret növekedésével a legelt és nem legelt területek közötti szignifikáns különbségek eltünése mutat. A homoki gyepi specialista fajok (Carex stenophylla, C. supina, Equisetum ramosissimum, Potentilla arenaria és Thymus glabrescens subsp. degenianus) nagyobb fajszámmal voltak jelen a nem legelt területeken, mint a legelteken. A legelés és taposás által okozott degradáció, valamint a szántóföldek, parlagok, városi területek és faültetvények alkotta „barátságtalan” környezetből érkező propagulum nyomás a gyomok fajgazdagságának növekedését okozta a legelt területeken. A legeltetett kvadrátokban megfigyeltük a közeli szántóföldekre és parlagokra jellemző fajokat, valamint a legelést közvetlenül kedvelő gyomfajokat is. A gyomfajok nagy része, különösen a legelt helyeken jelenlévők, képesek a zoochoria általi terjedésre (mint az Apera spica-venti, Conyza canadensis, Erodium cicutarium, Eryngium campestre, Poa bulbosa és Scleranthus annuus).

Eredményeinkre alapozva a nagytestű szarvasmarhafélékkel hagyományosan, közepes nyomással ( 0,5 állategység/hektár) történő legeltetés alkalmas kezelési mód lehet a szikes élőhelyek biodiverzitásának megőrzésére és növelésére. A homoki gyepekben ennél alacsonyabb nyomású vagy rövidebb időintervallumú legeltetés javasolható annak érdekében, hogy a területen a természetvédelmi értékek ne sérüljenek. 
Köszönetnyilvánítás - Köszönet illeti Deák Balázst, Valkó Orsolyát, Török Pétert, Tóthmérész Bélát és Kelemen Andrást a kutatásban nyújtott segítségükért. Továbbá, köszönet illeti a bírálókat munkájukért és hasznos tanácsaikért. A kutatást az OTKA PD 115627, OTKA PD 111807, OTKA K 116639 és NKFIH K 119225 kutatási pályázatok támogatták.

\section{Irodalomjegyzék}

Albert, Á.-J., Kelemen, A., Valkó, O., Miglécz, T., Csecserits, A., Rédei, T., Deák, B., Tóthmérész, B. \& Török, P. (2014): Secondary succession in sandy old-fields: A promising example of spontaneous grassland recovery. - Appl. Veg. Sci. 17: 214-224. doi: https://doi.org/10.1111/avsc.12068

Borhidi, A. (1995): Social behaviour types, the naturalness and relative ecological indicator values of the higher plants in the Hungarian Flora. - Acta Bot. Hung. 39: 97-181.

Burai, P., Deák, B., Valkó, O. \& Tomor, T. (2015): Classification of herbaceous vegetation using airborne hyperspectral imagery. - Remote Sens. 7: 2046-2066. doi: https://doi.org/10.3390/ rs70202046

de Bello, F., Lepš, J. \& Sebastià, M.-T. (2007): Grazing effects on the species-area relationship: Variation along a climatic gradient in NE Spain. - J. Veg. Sci. 18: 25-34. doi: https://doi. org/10.1111/j.1654-1103.2007.tb02512.x

Deák, B., Valkó, O., Alexander, C., Mücke, W., Kania, A., Tamás, J. \& Heilmeier, H. (2014a): Finescale vertical position as an indicator of vegetation in alkali grasslands - Case study based on remotely sensed data. - Flora 209: 693-697. doi: https://doi.org/10.1016/j.flora.2014.09.005

Deák, B., Valkó, O., Török, P. \& Tóthmérész, B. (2014b): Solonetz meadow vegetation (Beckmannion eruciformis) in East-Hungary - An alliance driven by moisture and salinity. - Tuexenia 34: 187-203. doi: https://doi.org/10.14471/2014.34.004

Deák, B., Valkó, O., Török, P., Kelemen, A., Tóth, K., Miglécz, T. \& Tóthmérész, B. (2015a): Reed cut, habitat diversity and productivity in wetlands. - Ecol. Complex. 22: 121-125. doi: https:// doi.org/10.1016/j.ecocom.2015.02.010

Deák, B., Valkó, O., Török, P., Kelemen, A., Miglécz, T., Szabó, Sz., Szabó, G. \& Tóthmérész, B. (2015b): Micro-topographic heterogeneity increases plant diversity in old stages of restored grasslands. - Basic Appl. Ecol. 16: 291-299. doi: https://doi.org/10.1016/j.baae.2015.02.008

Deák, B., Valkó, O., Török, P. \& Tóthmérész, B. (2016a): Factors threatening grassland specialist plants - A multi-proxy study on the vegetation of isolated grasslands. - Biol. Conserv. 204: 255-262. doi: https://doi.org/10.1016/j.biocon.2016.10.023

Deák, B., Tóthmérész, B., Valkó, O., Sudnik-Wójcikowska, B., Moysiyenko, I. I., Bragina, T. M., Apostolova, I., Dembicz, I., Bykov, N. I. \& Török, P. (2016b): Cultural monuments and nature conservation: a review of the role of kurgans in the conservation and restoration of steppe vegetation. - Biodivers. Conserv. 25: 2473-2490. doi: https://doi.org/10.1007/s10531-016-1081-2

Deák, B., Hüse, B. \& Tóthmérész, B. (2016c): Grassland vegetation in urban habitats - Testing ecological theories. - Tuexenia 36: 379-393. doi: https://doi.org/10.14471/2016.36.017

Deák B., Tölgyesi Cs., Kelemen A., Bátori Z., Gallé R., Bragina T. B., Yerkin A. I. \& Valkó O. (2018): The effects of micro-habitats and grazing intensity on the vegetation of burial mounds in the Kazakh steppes. - Plant Ecol. Divers. 10: 509-520. doi: https://doi.org/10.1080/1755087 4.2018.1430871

Horváth, F., Dobolyi, K., Morschhauser, T., Lőkös, L., Karas, L. \& Szerdahelyi, T. (1995): Flóra adatbázis 1.2. Taxon-lista és attributum állomány - MTA ÖBKI, Vácrátót, 267 p. 
Jentsch, A. \& Beyschlag, W. (2003): Vegetation ecology of dry acidic grasslands in the lowland area of central europe. Flora 198: 3-25. doi: https://doi.org/10.1078/0367-2530-00071

Kovácsné Koncz, N., Béri, B., Deák, B., Kelemen, A., Radócz, Sz. \& Valkó, O. (2015): Mély fekvésű gyepek élőhely kezelése különböző szarvasmarhafajták legeltetésével. - 27. Georgikon Napok, Cikkadatbázis. pp. 225-234.

Lindborg, R., Plue, J., Andersson, K. \& Cousins, S.A.O. (2014): Function of small habitat elements for enhancing plant diversity in different agricultural landscapes. - Biol. Conserv. 169: 206-213. doi: https://doi.org/10.1016/j.biocon.2013.11.015

Mann, S. \& Tischew, S. (2010): Role of megaherbivores in restoration of species-rich grasslands on former arable land in floodplains. - Waldökol. Online 10: 7-15.

Metera, E., Sakowski, T., Słoniewski, K. \& Romanowicz, B. (2010): Grazing as a tool to maintain biodiversity of grassland - A review. - Anim. Sci. Pap. Rep. 28: 315-334.

Morgan, R. P. C. (2008): Soil erosion and conservation. - Longman, London, 298 pp.

Novák, T., Négyesi, G., Andrási, B. \& Buró, B. (2014): Alluvial plain with wind-blown sand dunes in South Nyírség, Eastern Hungary. - In: Świtoniak, M. \& Charzynski, P. (Eds.): Soil sequences atlas. Nicholaus Copernicus University Press, Torun, pp. 181-197.

Olff, H. \& Ritchie, M. E. (1998): Importance of herbivore type and scale. - Trends Ecol. Evol. 13: 261-265. doi: https://doi.org/10.1016/S0169-5347(98)01364-0

Poschlod, P. \& Wallis de Vries, M. F. (2002): The historical and socioeconomic perspective of calcareous grasslands - Lessons from the distant and recent past. - Biol. Conserv. 104: 361-376. doi: https://doi.org/10.1016/S0006-3207(01)00201-4

$\mathrm{R}$ Core Team (2016): R: A language and environment for statistical computing. R Foundation for Statistical Computing, Vienna, Austria. URL https://www.R-project.org/

Schenk, H. J. (2006): Root competition: beyond resource depletion. - J. Ecol. 94: 725-739. doi: https://doi.org/10.1111/j.1365-2745.2006.01124.x

Tälle, M., Deák, B., Poschlod, P., Valkó, O., Westerberg, L. \& Milberg, P. (2016): Grazing vs. mowing: a meta-analysis of biodiversity benefits for grassland management. - Agric. Ecosys. Environ. 15: 200-212. doi: https://doi.org/10.1016/j.agee.2016.02.008

Tóth, E., Deák, B., Valkó, O., Kelemen, A., Miglécz, T., Tóthmérész, B. \& Török, P. (2016): Livestock type is more crucial than grazing intensity: traditional cattle and sheep grazing in shortgrass steppes. - Land Degrad. Dev. doi: https://doi.org/10.1002/ldr.2514

Tölgyesi, C., Bátori, Z., Erdős, L., Gallé, R. \& Körmöczi, L. (2015): Plant diversity patterns of a Hungarian steppe-wetland mosaic in relation to grazing regime and land use history. - Tuexenia 35: 399-416. doi: https://doi.org/10.14471/2015.35.006

Török, P., Valkó, O., Deák, B., Kelemen, A. \& Tóthmérész, B. (2014): Traditional cattle grazing in a mosaic alkali landscape: Effects on grassland biodiversity along a moisture gradient. - PLoS ONE 9: e97095. doi: https://doi.org/10.1371/journal.pone.0097095

Valkó, O., Török, P., Matus, G. \& Tóthmérész, B. (2012): Is regular mowing the most appropriate and cost-effective management maintaining diversity and biomass of target forbs in mountain hay meadows? - Flora 207: 303-309. doi: https://doi.org/10.1016/j.flora.2012.02.003

Valkó, O., Zmihorski, M., Biurrun, I., Loos, J., Labadessa, R. \& Venn, S. (2016a): Ecology and conservation of steppes and semi-natural grasslands. - Hacquetia 15: 5-14. doi: https://doi. org/10.1515/hacq-2016-0021

Valkó, O., Deák, B., Magura, T., Török, P., Kelemen, A., Tóth, K., Horváth, R., Nagy, D.D., Debnár, Z., Zsigrai, G., Kapocsi, I. \& Tóthmérész, B. (2016b): Supporting biodiversity by prescribed burning in grasslands - A multi-taxa approach. - Sci. Total Environ. 572: 1377-1384. doi: https:// doi.org/10.1016/j.scitotenv.2016.01.184 
Valkó, O., Deák, B., Török, P., Kirmer, A., Tishew, S., Kelemen, A., Tóth, K., Miglécz, T., Radócz, S., Sonkoly, J., Tóth, E., Kiss, R., Kapocsi, I. \& Tóthmérész, B. (2016c): High-diversity sowing in establishment windows: a promising new tool for enhancing grassland biodiversity. - Tuexenia

36: 359-378. doi: https://doi.org/10.14471/2016.36.020

Zar J.H. (1999): Biostatistical Analysis. - Prentice Hall, New Jersey, 663 p.

\title{
Scale dependent effects of grazing - species richness of alkaline and sand grassalands
}

\author{
Laura Godó \\ University of Debrecen, Department of Ecology, \\ Egyetem tér 1, H-4032 Debrecen, Hungary \\ e-mail:godolaura0306@gmail.com
}

Traditionally managed pastures have a crucial role in maintaining grassland biodiversity. We studied the effects of grazing on the species richness and composition of two alkaline and one sand grassland type, at ten spatial scales. At each grassland type we sampled the vegetation of five extensively grazed and five non-grazed sites with a series of nested plots. We found that grazing affected differently the alkali and sand grassland types and had a significant effect on their species richness even at small scales. Due to the increased small-scale heterogeneity and lower rate of competition, total species richness and the species richness of specialists was higher in grazed alkaline grasslands. In both alkaline grassland types, total species richness increased in a similar manner across plot sizes regardless of management. In sand grasslands grazing decreased the species richness of specialists while increased the species richness of weeds. According to our results traditional herding with a moderate grazing pressure can be a suitable tool for maintaining biodiversity of alkaline grasslands. While for the appropriate management of sand grasslands we propose lower grazing pressure or grazing in shorter periods.

Keywords: extensive grazing, generalist, grassland conservation, pasture management, specialist, weed 